\title{
Új és hagyományos irányok a gyermekkori akut lymphoblastos leukaemia biológiájában és ellátásában
}

\author{
Egyed Bálint ${ }^{1,2}$ - Kovács Gábor dr. ${ }^{1}$ - Kutszegi Nóra dr. ${ }^{2}$ \\ Rzepiel Andrea ${ }^{1}$ - Csányiné Sági Judit dr. ${ }^{2}$ - Erdélyi Dániel János ${ }^{1}$ \\ Müller Judit dr. ${ }^{1}$ - Félné Semsei Ágnes dr. ${ }^{2}$
}

Semmelweis Egyetem, Általános Orvostudományi Kar, ${ }^{1}$ II. Gyermekgyógyászati Klinika,

${ }^{2}$ Genetikai, Sejt- és Immunbiológiai Intézet, Budapest

\begin{abstract}
Az utóbbi néhány évtized klinikai előrelépéseinek köszönhetően az akut lymphoblastos leukaemiás (ALL-) gyermekek nagy hányada ma az első vonalbeli kemoterápiás protokollok révén meggyógyul, és küzd a kortársak közé való visszatérés problémáival. Azonban a betegek jelentős részénél súlyos akut és késői terápiás mellékhatásokkal kell számolni. Emellett egyes betegcsoportok (például MLL-átrendeződéssel, hipodiploiditással, IKZFl-mutációval vagy korai prekurzor T-sejtes fenotípussal jellemezhető betegek) túlélése messze elmarad az átlagostól. Számukra nyújtanak jobb klinikai kilátásokat az újabb betegellátási stratégiák: komplex géndiagnosztika, molekulárisan célzott daganatgátlás, immunonkológia és sejtterápia. Harminc feletti azon géneknek a száma, amelyek eltéréseit azonosították leukaemiás lymphoblastokban, és patobiológiai szerepük is valamennyire ismert. Ismerünk olyan betegcsoportot is (Philadelphia-like B-sejtes ALL), ahol a génexpressziós profilalkotás ad alapot a tirozin-kináz-inhibitorok használatának. A leukaemiaasszociált immunfenotípus diagnóziskori áramlási citometriás meghatározásával és genetikai módszerekkel követhetővé vált a minimális residualis betegség. A blastfelszíni differenciációs klaszterek (elsősorban CD19, CD20 és CD22 a malignus B-sejteken) epitópjai monoklonális antitestekkel támadhatók. Fokozható a tumorellenes immunitás is, részben szintén a tumor sejtfelszíni markereinek (bispecifikus T-sejt-kapcsolóknál, kiméra antigénreceptorú T-sejtes terápiánál), részben pedig a tumorspecifikus immunsejteknek (immunellenőrzőpont-gátlóknál) a kihasználása révén. A jelen közleményben áttekintést kívánunk adni a patogenetika új irányairól, a betegségkövetés modern módjairól és a célzott citotoxicitás innovatív lehetőségeiről biztató klinikai tanulmányok alapján.

Orv Hetil. 2018; 159(20): 786-797.
\end{abstract}

Keywords: akut lymphoblastos leukaemia, patogenezis, toxicitás, immunterápia, célzott molekuláris terápia

\section{New and traditional directions in the biology and management of childhood acute lymphoblastic leukemia}

Owing to clinical trials and improvement over the past few decades, the majority of children with acute lymphoblastic leukemia (ALL) survive by first-line chemotherapy and combat with the problems of returning to community. However, many patients may have severe acute or late therapeutic side effects, and the survival rate in some groups (e.g., patients with MLL rearrangements, hypodiploidy, IKZFl mutation or early precursor T cell phenotype) is far behind the average. Innovative strategies in medical attendance provide better clinical outcomes for them: complete gene diagnostics, molecularly targeted anticancer treatment, immuno-oncology and immune cell therapy. The number of genes with identified alterations in leukemic lymphoblasts is over thirty and their pathobiologic role is only partly clear. There are known patient groups where the use of specific drugs is based on gene expression profiling (e.g., tyrosine kinase inhibitors in Philadelphia-like B-cell ALL). The continuous assessment of minimal residual disease became a routine due to the determination of a leukemia-associated immunophenotype by flow cytometry or a sensitive molecular marker by molecular genetics at diagnosis. Epitopes of cluster differentiation antigens on blast surface (primarily CD19, CD20 and CD22 on malignant B cells) can be attacked by monoclonal antibodies. Moreover, antitumor immunity can be strengthened utilizing either cell surface markers (bispecific T cell engagers, chimeric antigen receptor $\mathrm{T}$ cell therapy) or tumor-specific immune cells (immune checkpoint inhibitors). This review gives an insight into current knowledge in these innovative therapeutic directions. 
Keywords: acute lymphoblastic leukemia, pathogenesis, toxicity, immunotherapy, molecular targeted therapy

Egyed B, Kovács G, Kutszegi N, Rzepiel A, Csányiné Sági J, Erdélyi DJ, Müller J, Félné Semsei Á. [New and traditional directions in the biology and management of childhood acute lymphoblastic leukemia]. Orv Hetil. 2018; 159(20): 786-797.

(Beérkezett: 2018. január 19.; elfogadva: 2018. március 8.)

\begin{abstract}
Rövidítések
$\mathrm{ABL}=$ Abelson murine leukemia viral oncogene homolog; ADCC $=$ antitestdependens sejtmediált citotoxicitás; ALL = akut lymphoblastos leukaemia; CALLA = common acute lymphoblastic leukemia antigen; CAR = kiméra antigénreceptor; $\mathrm{CD}=$ differenciációs klaszter; $\mathrm{CDC}=$ komplementdependens citotoxicitás; $\mathrm{cIg} / \mathrm{sIg}=$ citoszolikus/sejtfelszíni immunoglobulin; CTLA4 = citotoxikus T-lymphocyta antigén-4; FC = áramlási citometria; $\mathrm{Fc}=$ kristályosítható fragmentum; HDAC = hiszton-deacetiláz; HLA = humánleukocyta-antigén; HSC = haemopoeticus össejt; HSCT = haemopoeticus össejt-transzplantáció; ICI = immunellenőrzőpont-gátló; JAK2 = Janus-kináz-2; KIT = v-kit Hardy-Zuckerman 4 feline sarcoma viral oncogene homolog; LAIP = leukaemiaasszociált immunfenotípus; $\mathrm{MHC}=$ fó hisztokompatibilitási komplex; $\mathrm{MRD}=$ minimális residualis betegség; $\mathrm{mTOR}=$ mammalian target of rapamycin; $\mathrm{PBMC}=$ a perifériás vér mononukleáris sejtjei; PCR = polimeráz-láncreakció $; \mathrm{PDI}=$ programozott sejthalál protein-1; PDGFRB = platelet derived growth factor receptor beta; $\mathrm{Ph}+=$ Philadelphia-transzlokáció-pozitív; Ph-like $=$ Philadelphia-transzlokáció-szerű; scFv = egyláncú variábilis ellenanyagfragmentum; TAA = tumorasszociált antigén; TCR $=$ T-sejtreceptor; $\mathrm{TdT}=$ terminális dezoxinukleotid-transzferáz; $\mathrm{TKI}=$ tirozin-kináz-inhibitor
\end{abstract}

Az akut lymphoid leukaemia terminus a lymphopoeticus rendszer immunológiailag és genetikailag heterogén malignus betegségcsoportját írja le. Az entitáson belül biológiai alapon elsősorban prekurzor B-sejtes és prekurzor T-sejtes akut lymphoblastos leukaemiát/lymphomát (BALL és T-ALL), valamint érett B-sejtes (Burkitt-típusú) leukaemiát/lymphomát különböztetünk meg $[1,2]$. A jelen közlemény az éretlen sejtalakokat érintő kórképcsoporttal foglalkozik (akut lymphoblastos leukaemia, ALL). Az ALL-es beteg pontos besorolásához szükséges a részletes immunfenotípus és a speciális genetikai eltérések karakterizálása. A kezelés alapvonala a szisztémás kemoterápia. Egyes szervek leukaemiás terheltsége (extramedullaris manifesztáció) további sugárterápiás (központi idegrendszeri érintettségben) vagy akár sebészi beavatkozásokat (okkult hereinfiltráció esetén) indikálhat a későbbi relapsusok megelőzésére [3]. Ha a várható túlélési esély alacsony (nagyon magas rizikó), akkor a sejtterápia is alternatívát kínál: a haemopoeticus őssejttranszplantáció (HSCT) jelenleg széles körben elterjedt beavatkozás, míg kezelésrefrakter vagy többször relabált esetekben a jövőben a génmódosított T-sejtes immunterápia is indokolt lehet. Ezzel a gyermekkori ALL ellátá- sában a jelenlegi onkoterápiás eszköztár gyakorlatilag minden eleme szerephez juthat.

A kemoterápia valószínúleg a modern célzott daganatgátló és immunonkológiai gyógyszerek bevezetésével sem szorul ki a gyermekkori ALL kezeléséből még jó ideig, de biztonságosabbá tehetó. A betegek farmakogenetikai tesztelése és a kemoterápiás szerek genotípus-alapú dozírozása szintén a gyógyulási arány növekedését szolgálhatja a toxikus mellékhatások visszaszorításával.

A prognosztikailag különböző betegcsoportok eltérő kezelési stratégiákat igényelnek. A csoportok elkülönítésében az ALL patobiológiájának számos új molekuláris felismerése nyújthat támpontot. A leukaemiás sejtek örökítőanyagának genomszintű vizsgálatával kimutatott szubmikroszkopikus eltérések a leukaemogenesis jobb megismerésén túl terápiás célpontokhoz is vezettek [4]. A kezelésre reagáló betegek residualis tumorsejtjeinek biológiai viselkedése előre jelezheti a késóbbi relapsusokat. A legtöbb esetben (több mint 90\%-ban) a recidívát okozó klón minor szubklón formájában már a diagnózis idején nyert biológiai mintákban jelen van, és terápiarezisztencia vagy klonális evolúció révén jut szelekciós előnyhöz [5].

\section{Növekvő incidencia és mögöttes etiológiai tényezők}

Az 1-18 éves gyermekek körében továbbra is a malignus neoplasiák jelentik a betegségek okozta mortalitás vezető okát (12\%) a balesetek mögött [6]. A korcsoportban az ALL a leggyakrabban elóforduló hematológiai malignitás, az összes daganatos megbetegedés 25-30\%-a. Ez hazánkban évi 60-70 új megbetegedést jelent [7]. Az esetek 85\%-át képviselő prekurzor B-sejtes altípus előfordulásának csúcsa 3-4 éves korra tehetó, míg a 15\%-ot reprezentáló T-sejtes altípus a 10-18 éves fiúk körében a leggyakoribb [8].

Megemlítendő, hogy a betegség incidenciája a modern iparosodott társadalmakban több évtizede enyhe emelkedő tendenciát mutat. A jelenségre magyarázatot a csecsemőkori túlzott higiénia miatt „tanítatlan”, ezáltal félresiklott immunitás, majd a banális infekciókra adott abnormális válasz szolgáltathat $[4,9,10]$. A fertőzés leukaemogenesisben játszott szerepét valószínúsíti, hogy több független vizsgálatban is alátámasztották a vándorlással járó populációkeveredés konzisztens kockázatemelő hatását a gyermekkori akut leukaemiák megjelenésére. Röviddel az új lakosok betelepülése után átlagosan más- 
félszeres relatív kockázatot figyeltek meg, ami mögött a behurcolt, adott területen addig ismeretlen patogének megjelenését sejtik $[11,12]$. Régóta próbálkoznak humán ALL-es mintákban leukaemogenesissel összefüggésbe hozható infektív ágens kimutatásával, azonban exogén virális, illetve mikrobiális szekvenciákat még érzékeny módszerekkel sem találtak [9]. Egyre inkább úgy tünik, hogy ennek a leukaemiatípusnak a kialakulása csak indirekt módon, fogékony egyének immundiszregulációján keresztül köthető kórokozókhoz. Az utóbbiak között az influenzavírusoknak lehet kiemelt szerepük [13, 14]. Az infekcióeredetű proliferatív stressz (citokinek, sejtes interakciók) feltételezhetően olyan miliőt teremt, amelyben egy genetikájából adódóan fogékony praeleukaemiás lymphoblastklón képes szelektálódni [15]. A deregulált immunválaszban ez a klón nem esik át apoptózison, és a jelen levő genotoxikus oxidatív stressz hatására szekunder mutációkat is felhalmoz. Végül ez az aberráns sejtvonal vezet az akut leukaemia manifesztációjához [4, 9, 10]. Az elmélet egybeesik a blastszintü molekuláris abnormitások többlépcsős (szekvenciális) kialakulásának modelljével (lásd a későbbiekben). A folyamat eredetének pontosítására Kinlen és Greaves inkább egymást kiegészítő, mintsem kizáró hipotéziseket dolgozott ki $[9,11]$. Az immunmechanizmusok etiológiai szerepét erősítik azok az eredmények, hogy a gyermekkori ALL rizikója asszociál bizonyos hisztokompatibilitásért felelős humánleukocytaantigén (HLA)-konstellációkkal. Megerősítették a $H L A-D P B 1 * 0201$ allél [16], korábban pedig leírták a $H L A-D R B 4^{*} 01$ allél [17] rizikónövelő hatását. A tanítatlan immunitás kóroki szerepét támogatja az anyatejes táplálás védőhatása a gyermekkori leukaemiák kialakulásában [18].

\section{Diagnózis és modern betegségkövetési módszerek}

Az ALL kórisméje csontvelői aspirátum vagy szükség esetén megfelelő csontvelő-biopsziás mintából készített szövettani metszet patológiai értékelésén alapszik. Az ALL-es minta elkülönítendő a nemritkán hasonló mikromorfológiájú akut myeloid leukaemiától, a Burkitt-sejtes leukaemiától és a kis kereksejtes daganatok (például neuroblastoma vagy Ewing-szarkóma) csontvelői áttétjétól. Ebben segít rendre a mieloperoxidáz-festés, a perjódsavSchiff-reakció és a CD45, CD9, CD56, illetve CD99 markerek immunhisztokémiai kimutatása [19]. A citomorfológiai értékelés mellett a diagnóziskor elengedhetetlen a citogenetikai, illetve a molekuláris genetikai vizsgálat és az immunfenotipizálás (1. táblázat). Prognosztikai értéküket nehéz lenne túlbecsülni. A diagnosztikus folyamat a minimális residualis betegség (MRD) későbbi monitorozására alkalmas érzékeny molekuláris marker vagy aberráns leukaemiaasszociált immunfenotípus (LAIP) keresésével zárul.

Akut leukaemiákban a betegeknek a diagnóziskor körülbelül $10^{12}$ neoplasztikus sejtje van, amelyek közül a klinikai és patomorfológiai komplett remisszió állapotában akár $10^{10}$ is visszamaradhat MRD-ként [20]. Az MRD mérése a jelenleg ismert legspecifikusabb és leginkább szenzitív marker a terápiás válasz követésére és a relapsusmentes túlélés előrejelzésére gyermekkori ALLben $[3,21,22]$. Becslésére két módszer terjedt el. A LAIP detektálásának elvén múködő multiparaméteres áramlási citometria (FC) gyorsan és viszonylag olcsón képes információt szolgáltatni a betegek nagy részének maradék betegségéről. Azonban a módszer standardizálása nehézkes, az eredmény pedig függ a vizsgáló személyétől. Még érzékenyebb és sokszor könnyebben reprodukálható a polimeráz-láncreakció (PCR), amely a malignus sejteken lévő antigénreceptorok vagy az immunglobulin-nehézláncok génátrendeződéseit, ritkábban a leukaemiaspecifikus génfúziós transzkripteket (ezek közül a BCR-ABLl használható megbízhatóan) mutatja ki. Hátránya viszont, hogy lassabb (pénz- és munkaigényes), és nem használható minden betegnél. Mindkét technikánál előfordulhatnak álnegatív eredmények: FC esetén a gyógyszerek (fóként szteroidok) indukálta immunfenotípus-moduláció, PCR esetén az oligoklonalitás, illetve a klonális evolúció nehezíti az MRD becslését. A hátrányok elkerülésére a jövő alternatívája a még szenzitívebb amplikonalapú új generációs szekvenálás. Ehhez molekuláris markerként az átrendeződött immunglobulin- és T-sejt-receptor-gének szolgálnak [23].

\section{A klasszikus kemoterápia alapvonalai}

Napjainkban a gyermekkori ALL kezelésének gerince a kombinált kemoterápia, amely ötből négy betegnél hatásosnak bizonyul a tartós remisszió elérésében [8]. Világszerte számos, nemzetközi klinikai vizsgálatok révén folyamatosan fejlesztett terápiás protokoll van érvényben, amelyek alapfelépítésükben hasonlók. Használatuk az ALL-es gyermekek ellátását korántsem teszi személyre szabottá, de előtérbe kerül a betegségprogresszió szempontjából különböző rizikójú betegcsoportok eltérő intenzitású kezelése (2. táblázat) [4, 24].

A kemoterápia kezdetének célja a citoredukció, a leukaemiás sejtproliferátum több mint 99\%-ának eradikációja, és ezáltal a komplett hematológiai remisszió elérése. Hatékonyságát mutatja, hogy a betegek 96-99\%-ában a kezelés első hónapjának végére visszaáll a normális haemopoesis [4]. Az ezt követő preszimptomatikus központi idegrendszeri kemoterápia (intravénás és intrathecalis gyógyszeradagolással) a meningealis eredetű relapsus megelőzésére szolgál. A vénás kezelés utolsó szakasza az MRD lehető legnagyobb mértékú eliminálását célozza, hiányában a betegek legtöbbje néhány hónapon belül relabálna a residualis tumorsejtek miatt [3]. A teljes hosszában kétéves kezelés utolsó szakasza a fóként szájon át történő gyógyszeradagolásból álló fenntartó terápia, amely a késői csontvelői relapsus megelőzését szolgálja. 


\begin{tabular}{|c|c|}
\hline Diagnosztikus lépés/metódus & Eredmény, osztályozás \\
\hline \multicolumn{2}{|l|}{ Citomorfológia } \\
\hline Csontvelői minta és perifériás vér kenete & $\begin{array}{l}\text { Lymphoid vagy differenciálatlan blastokkal infiltrált } \\
\text { (az ALL diagnózisa akkor mondható ki, ha arányuk legalább } 20 \% \text { az } \\
\text { összes magvas sejthez viszonyítva) }\end{array}$ \\
\hline $\begin{array}{l}\text { Lumbálpunkcióval nyert liquor vizsgálata (standard citospin prepará- } \\
\text { tum, sejtszámlálás Fuchs-Rosenthal- vagy Nageotte-kamrában) }\end{array}$ & Központi idegrendszeri érintettség besorolása \\
\hline \multicolumn{2}{|l|}{ Immunfenotípus, immunhisztokémia } \\
\hline $\begin{array}{l}\text { Myeloperoxidáz (MPO)-festés, illetve a CD13- és a CD33-marker } \\
\text { kimutatása }\end{array}$ & Az akut myeloid leukaemiától való elkülönítés alapja \\
\hline $\begin{array}{l}\text { A B-sejtvonal markereinek kimutatása: CD19, CD79a, cCD22 } \\
\text { (közülük legalább kettő); továbbiak: TdT, CD10, CD20, CD24, } \\
\text { cIgM, sIg ( } \kappa \text { vagy } \lambda)\end{array}$ & \multirow{3}{*}{$\begin{array}{l}\text { A B-sejtes ALL altípusai: } \\
\text { Pro-B/B-I }\left(\mathrm{CD} 19 / \mathrm{CD} 79 \mathrm{a} / \mathrm{cCD} 22 / \mathrm{CD} 34^{+}\right) \\
\text {Common/B-II }\left(\mathrm{CD} 19^{+} / \mathrm{CDIO}^{+} / \mathrm{cIgM}^{-}\right) \\
\text {Pre-B/B-III }\left(\mathrm{CD}^{-} 4^{-} / \mathrm{cIgM}^{+} / \mathrm{sIg}^{-}\right) \\
\text {Érett B/B-IV }\left(\mathrm{sIg}^{+} / \mathrm{TdT}^{-}\right) \\
\text {A T-sejtes ALL altípusai: } \\
\text { Pro-T/T-I }\left(\mathrm{cCD} 3 / \mathrm{CD}^{+}\right) \\
\text {Pre-T/T-II }\left(\mathrm{CD} 2 / \mathrm{CD}^{+}\right) \\
\text {Corticalis T/T-III }\left(\mathrm{CDla}^{+}\right) \\
\text {Érett T/T-IV }\left(\mathrm{CD}^{+} / \mathrm{CDla}^{-}\right) \\
\end{array}$} \\
\hline $\begin{array}{l}\text { A T-sejtvonal markereinek kimutatása: cCD3; továbbiak: TdT, CDla, } \\
\text { CD2, CD5, CD7, CD4, CD8, TCR } \alpha / \beta \text { vagy } \gamma / \delta\end{array}$ & \\
\hline $\begin{array}{l}\text { Az őssejt, illetve a myeloid sejt markereinek kimutatása: CD34, } \\
\text { CD13, CD33, CD117 }\end{array}$ & \\
\hline \multicolumn{2}{|l|}{ Citogenetika, molekuláris genetika } \\
\hline $\begin{array}{l}\text { Közülük legalább az egyik: } \\
\text { Nagy felbontású G-sávozás } \\
\text { Fluoreszcens in situ hibridizáció (FISH) } \\
\text { Polimeráz-láncreakció (PCR) } \\
\text { Újabb módszerek: } \\
\text { Komparatív genomhibridizáció (CGH) } \\
\text { Génexpressziós profilalkotás } \\
\text { Új generációs szekvenálás (NGS) }\end{array}$ & $\begin{array}{l}\text { B-sejtes ALL visszatérő genetikai abnormitásokkal*: } \\
\text { t(9;22)(q34;q11.2): BCR-ABL1 } \\
\text { t(v;11 } 23): M L L \text { átrendeződése } \\
\text { t(12;21)(p13;q22): ETV6-RUNXI (TEL-AMLI) } \\
\text { Hiperdiploiditás } \\
\text { Hipodiploiditás } \\
\text { t } 5 ; 14)(\mathrm{q} 31 ; \mathrm{q} 32): I L 3-I G H \\
\text { t(1;19)(q23;p13.3): TCF3-PBXI } \\
\text { 21-es intrakromoszomális amplifikáció } \\
\text { Ph-like ALL } \\
\text { T-sejtes ALL visszatérő genetikai abnormitásokkal*: } \\
\text { ETP (early T-precursor, korai T-prekurzor) ALL: } \\
\text { FLT3/NRAS/KRAS/IDHl/IDH2/DNMT3A+ } \\
\text { NOTCH1/CDKN1/CDKN2- }\end{array}$ \\
\hline
\end{tabular}

*Az Egészségügyi Világszervezet (WHO) 2016-ban revideált, 2008-ban kiadott klasszifikációja szerint.

$\mathrm{ABLl}=$ Abelson murine leukemia viral oncogene homolog $1 ; \mathrm{ALL}=$ akut lymphoblastos leukaemia AMLl = akut myeloid leukaemia-1 protein; $\mathrm{BCR}$ = breakpoint cluster region; $\mathrm{CD}=$ differenciációs klaszter; $\mathrm{CDKN}=$ cyclin dependent kinase inhibitor; $\mathrm{cIg} / \mathrm{sIg}=$ citoszolikus/sejtfelszíni immunglobulin; DNMT = DNS-metiltranszferáz; ETV6 = ets variant gene 6 (TEL oncogene); FLT3 = fms related tyrosine kinase 3; IDH = isocitrate dehydrogenase; IGH = immunoglobulin heavy locus; IL3 = interleukin-3 (colony-stimulating factor, multiple); KRAS = Kirsten rat sarcoma viral oncogene homolog; $\mathrm{MLL}=$ mixed-lineage leukemia; $\mathrm{NOTCH}=$ Notch (Drosophila) -homológ; NRAS $=$ neuroblastoma; PBXI = pre-B-cell leukemia homeobox $1 ; \mathrm{Ph}$-like = Philadelphia-transzlokáció-szerú; RAS = viral (v-ras) oncogene homolog; RUNXI = Runt-related transcription factor 1 ; TCF3 = transcription factor 3; TCR = T-sejt-receptor; TdT = terminális dezoxinukleotid-transzferáz

Az ALL kemoterápiájában speciális, hogy a kezelés felépítése - más malignitásoktól eltérően - javarészt nem blokkos, hanem folyamatos, elnyújtott gyógyszeradagolás történik [25]. Ezenfelül kiemelendó a glükokortikoidok igen jelentôs szerepe a kezelésben.

A nagy dózisú, igen intenzív kemoterápia óhatatlanul toxikus mellékhatásokat okoz a szövetekben $[3,8,26$, 27]. Ezek jelentkezhetnek nemritkán életet veszélyeztető, heveny formában [24], amely adverz események rendszeres felmérése és értékelése a hazánkban múködő Magyar Gyermekonkológiai Hálózat egyik kiemelt törekvése [28]. Ennek nyomán munkacsoportunk is készséges résztvevője és szervezője nemzetközi gyógyszer- biztonsági vizsgálatoknak [29]. A toxicitás megelőzésére több citosztatikumnak új, biztonságosabb formája is létezik (fóként pegilált vagy liposzomális kivitel) [26], illetve segítséget nyújt a vérplazma gyógyszerszintjének rutinszerú monitorozása (hazánkban évek óta figyelt paraméter a metotrexátkoncentráció, de bevezetés alatt áll az aszparaginázaktivitás mérése is). Korábbi saját farmakogenetikai vizsgálataink eredményei csatlakoznak ahhoz a nemzetközi irányvonalhoz, hogy bizonyos génvariánsok előzetes meghatározása (kemoterapeutikumokkal kölcsönható metabolizáló enzimek, transzporterek és hisztokompatibilitásért felelős antigének polimorf locusainak genotipizálása) előrevetítheti a nem kívánt mel- 
2. táblázat | Prognosztikai faktorok gyermekkori ALL-ben

\begin{tabular}{|c|c|c|c|}
\hline Jelző & Kedvező prognosztikai faktor & Prognosztikailag hátrányos faktor & Klinikai felhasználás \\
\hline \multicolumn{4}{|l|}{ Demográfiai és klinikai sajátságok } \\
\hline Diagnóziskori életkor & $\geq 1-<6$ év & $<1$ vagy $\geq 6$ év & Betegstratifikáció \\
\hline Nem & Leány & Fiú & Nincs \\
\hline Rassz/etnikum & Fehér, ázsiai & Fekete, hispán & Nincs \\
\hline Kezdeti fehérvérsejtszám & Alacsony $(<20 \mathrm{G} / 1)$ & Magas $(\geq 20 \mathrm{G} / 1)$ & Betegstratifikáció \\
\hline $\begin{array}{l}\text { Lymphadenomegalia, hepatosple- } \\
\text { nomegalia }\end{array}$ & Nincs & Masszív & Nincs \\
\hline Központi idegrendszeri leukaemia & Nincs & $\begin{array}{l}\text { Bizonyítható (lymphoblastok + } \\
\text { pleocytosis) }\end{array}$ & $\begin{array}{l}\text { Központi idegrendszeri kemoterá- } \\
\text { pia és cranialis radioterápia } \\
\text { mértéke }\end{array}$ \\
\hline Hereérintettség & Nincs & Van & $\begin{array}{l}\text { Lokális radioterápia vagy } \\
\text { kasztráció mérlegelése }\end{array}$ \\
\hline \multicolumn{4}{|l|}{ Tumorbiológiai jelzók } \\
\hline $\begin{array}{l}\text { FAB-klasszifikáció szerinti } \\
\text { patomorfológia }\end{array}$ & $\mathrm{Ll}$ & $\mathrm{L} 2$ & Nincs \\
\hline Immunfenotípus & B-sejtes ALL & T-sejtes ALL & $\begin{array}{l}\text { Gyógyszerdozírozás, központi } \\
\text { idegrendszeri terápia }\end{array}$ \\
\hline Citogenetika & $\begin{array}{l}\text { ETV6-RUNXI transzlokáció, } \\
\text { hiperdiploiditás, } 4 \text {-es és } 10 \text {-es } \\
\text { kromoszóma triszómiája }\end{array}$ & $\begin{array}{l}B C R-A B L 1 \text { transzlokáció, } M L L \\
\text { génátrendeződések, hipodiploidi- } \\
\text { tás }\end{array}$ & $\begin{array}{l}\text { Betegstratifikáció, csontvelő-átül- } \\
\text { tetés indikációi, célzott molekulá- } \\
\text { ris inhibitorok }\end{array}$ \\
\hline Molekuláris genetika & $E R G$-deletiók & $\begin{array}{l}\text { IKZFI-deletiók vagy -mutációk, } \\
\text { Ph-like ALL }\end{array}$ & Célzott kinázgátló terápia \\
\hline \multicolumn{4}{|l|}{ Korai terápiás válasz } \\
\hline $\begin{array}{l}\text { Egyhetes glükokortikoid-előkeze- } \\
\text { lésre adott válasz } \\
\text { (8. napi perifériás vérkenet } \\
\text { értékelése) }\end{array}$ & $\begin{array}{l}\mathrm{ABC}<1000 / \mu \mathrm{l} \text {, } \\
\text { úgynevezett jó glükokortikoidvá- } \\
\text { lasz (PGR, prednisone-good } \\
\text { responder) }\end{array}$ & $\begin{array}{l}\mathrm{ABC} \geq 1000 / \mu \mathrm{l}, \\
\text { úgynevezett rossz glükokortikoid- } \\
\text { válasz }(\mathrm{PPR}, \text { prednisone-poor } \\
\text { responder) }\end{array}$ & Betegstratifikáció \\
\hline $\begin{array}{l}\text { Csontvelói lymphoblast-arány 2-4 } \\
\text { hetes kombinált kemoterápia után } \\
\text { (15. és 33. napi csontvelői kenet } \\
\text { értékelése) }\end{array}$ & Ml-státusz (<5\% blast) & $\begin{array}{l}\text { M2- ( } 5-25 \% \text { blast) vagy M3- } \\
\text { ( } \geq 25 \% \text { blast) státusz }\end{array}$ & Betegstratifikáció \\
\hline $\begin{array}{l}\text { FC-alapú MRD-értékelés ( } 15 . \\
\text { napi csontvelői mintán) }\end{array}$ & $\begin{array}{l}\text { Alacsony }(<0,1 \%) \text { vagy mérhetet- } \\
\text { len MRD }\end{array}$ & Perzisztáló MRD ( $\geq 0,1 \%)$ & Betegstratifikáció \\
\hline $\begin{array}{l}\text { MRD a kombinált kemoterápia } \\
\text { alatt (33. és } 78 \text {. nap, } 3-4 \text {. hónap) }\end{array}$ & $\begin{array}{l}\text { Alacsony }(<0,01 \%) \text { vagy } \\
\text { mérhetetlen MRD }\end{array}$ & Perzisztáló MRD ( $\geq 0,01 \%)$ & $\begin{array}{l}\text { HSCT indikációja és újabb } \\
\text { vizsgálatokban időzítése }\end{array}$ \\
\hline
\end{tabular}

$\mathrm{ABC}=$ abszolút blastszám; $\mathrm{ABLl}=$ Abelson murine leukemia viral oncogene homolog $1 ; \mathrm{ALL}=$ akut lymphoblastos leukaemia; $\mathrm{BCR}=$ breakpoint cluster region; ERG = v-ets avian erythroblastosis virus E26 oncogene homolog; ETV6 = ets variant gene 6 (TEL oncogene); FAB = FrenchAmerican-British; FC = áramlási citometria; HSCT = haemopoeticus őssejt-transzplantáció; IKZFl = IKAROS family zinc finger 1 ; MLL = mixed-lineage leukemia; MRD = minimális residualis betegség; Ph-like = Philadelphia-transzlokáció-szerú; RUNXI = Runt-related transcription factor 1

lékhatásokra való hajlamot [30-32]. Sokat fejlődött továbbá a kiegészítő (szupportív) terápia, amelynek hála az akut adverz reakciók jól kezelhetôvé váltak. Így a fejlett kemoterápia drámai javulást hozott a gyermekkori ALL gyógyíthatóságában: míg az 1960-as években az ötéves tünetmentes túlélés $10 \%$ alatt volt, mára eléri a $80 \%$-ot [33]. A hazai kezelési eredmények évek óta alig maradnak el a nyugat-európai országokban elértektől [34]. A magas túlélési esélyeknek megfelelően az utóbbi időben a figyelem középpontjába kerültek a daganatellenes terápia hosszú távú, késôi szövődményei, amelyek erősen ronthatják a túlélők felnőttkori életminőségét $[35,36]$.

\section{Molekuláris patogenezis és új, patogenetikai alapú kezelési lehetőségek}

Az ALL multifaktoriális eredetú kórkép [4]. A genetikai determináltság és a környezeti hatások együttes szerepére utalnak az ikerkutatási eredmények is. Egypetéjü ikrekben igen magas (monochorialis placenta mellett közel 100\%-os) konkordanciát mutat az $M L L$-gén átrendeződéséhez köthető csecsemókori ALL. Ezzel szemben az $M L L$-gént többnyire nem érintő esetek a leggyakrabban 2 és 5 éves kor között alakulnak ki, és az ikrek közti konkordancia csak 10-15\%. Míg az előbbi esetben a leukae- 
mogenesis feltételezhetően már praenatalisan közel teljes, addig az utóbbiban a betegség in utero iniciálódhat, és a manifesztációhoz további, részben környezeti (vagy sztochasztikus) faktorok szükségesek [4]. Jelentős hajlamosító szereppel bír több, főként a DNS-hiba-javítást érintő öröklődő szindróma (Bloom-szindróma, ataxia teleangiectasia, Li-Fraumeni-szindróma, Nijmegenbreakage szindróma, Down-szindróma) [10]. Bár az utóbbi kórképek az ALL incidenciájának kevesebb, mint 5\%-áért felelősek, a legtöbb betegnél számolni lehet a visszatérő genetikai abnormitások legalább valamelyikével.

A betegek szomatikus géneltérései az intracelluláris múködések széles spektrumát befolyásolják. A tumorprogresszió és a mögöttes klonális evolúció vizsgálatának céljából gyermekkori ALL-esek teljes exomszekvenálással történő követése hat kulcsfontosságú molekuláris jelpálya visszatérő géneltéréseit fedte fel [37]:

1. A lymphoid fejlődési vonal transzkripcionális regulátorai 85\%-ban voltak érintettek (jellemző gének: PAX5, IKZF1, EBF1, TCF3, RUNX1, NOTCH1).

2. A Ras-szignálút 65\%-ban volt érintett (KRAS, NRAS, PTPN11, FLT3).
3. Az epigenetikai módosítók 65\%-ban voltak érintettek (WHSC1, CREBBP, MLL).

4. A sejtciklus szabályozói $60 \%$-ban voltak érintettek (CDKN2A/2B, TP53, RBI).

5. A nukleozidmetabolizmus génjei 45\%-ban voltak érintettek (NT5C2).

6. A JAK-STAT jelátviteli út $25 \%$-ban volt érintett (JAK2, CRLF2).

Lényegében három olyan mechanizmust különböztethetünk meg, amelyek révén ezek a gének abnormális funkcióhoz jutnak, és a lymphopoesist eltérítik a blastok transzformációja és immortalizációja felé [38]:

1. Gyakori a fúziós génhez vezető transzlokáció, aminek következtében aberráns kiméra protein keletkezik. Ez sokszor a leukaemia klinikai manifesztációja előtt évekkel kimutatható neonatalis vérmintákból [39]. Idetartozik a gyermekkori ALL leggyakoribb genetikai eltérése, két haemopoeticus transzkripciós faktor génjének (ETV6 és RUNXI) a fúziója. Prognosztikai jelentőségű az $M L L$-gén fúziója körülbelül 70 lehetséges partnergénnel, ami a csecsemókori leukaemiák 80\%-ában kimutatható. Gyermekkori ALL-ben nem

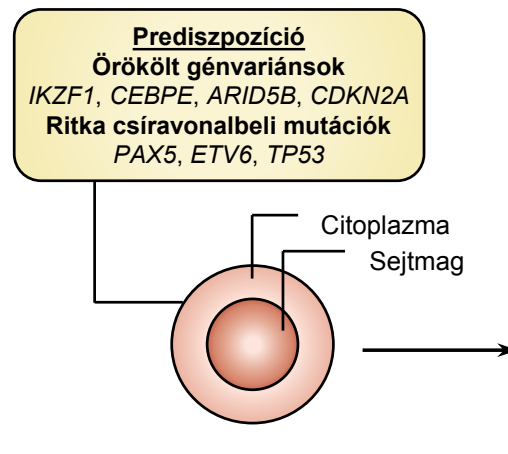

HSC
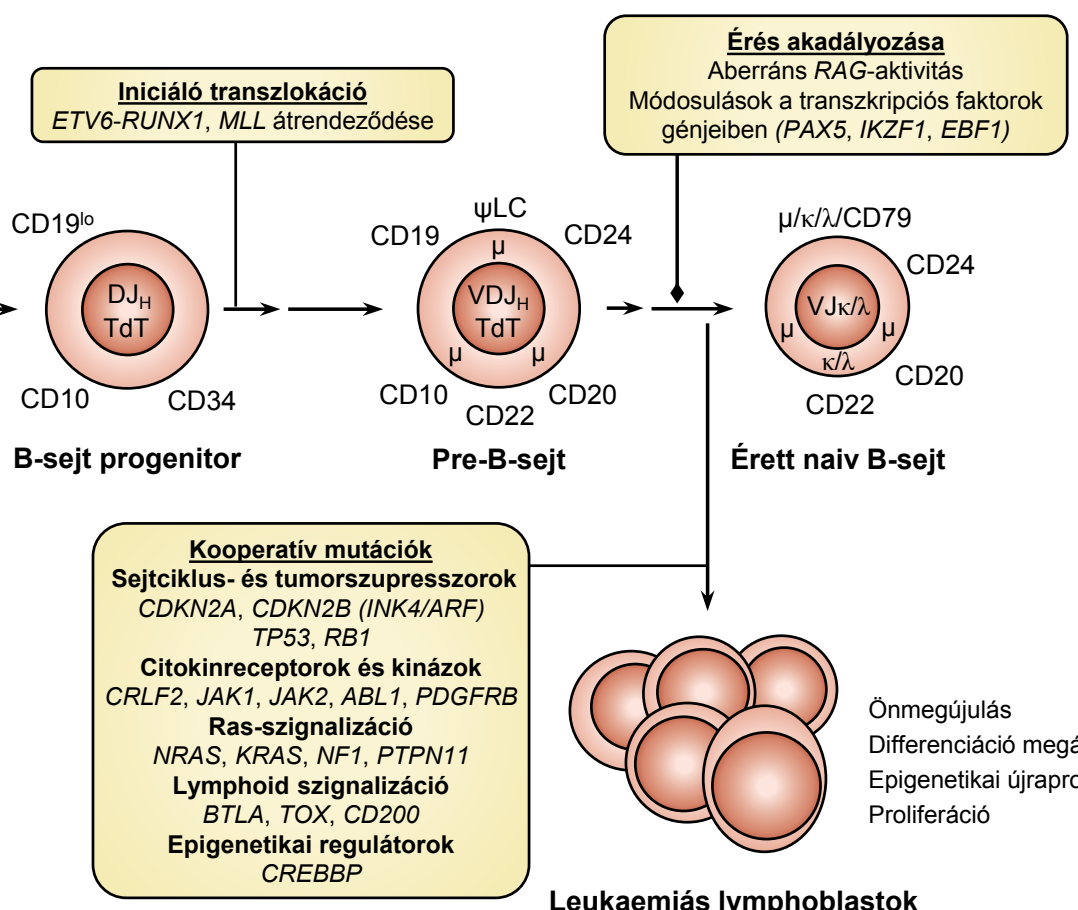

Önmegújulás

Differenciáció megállása

Epigenetikai újraprogramozás Proliferáció

Leukaemiás lymphoblastok

\begin{abstract}
1. ábra $\quad$ Az ALL patogenezise a B-sejtes fejlődési vonal példáján
$\mathrm{ABLl}=$ Abelson murine leukemia viral oncogene homolog $1 ;$ ARID5B = AT-rich interaction domain 5B; BTLA = B and T lymphocyte associated; $\mathrm{CD}=$ differenciációs klaszter; $\mathrm{CDKN} 2 \mathrm{~A} / 2 \mathrm{~B}=$ cyclin dependent kinase inhibitor $2 \mathrm{~A} / 2 \mathrm{~B} ; \mathrm{CEBPE}=\mathrm{CCAAT} /$ enhancer binding protein epsilon; PAX5 $=$ paired box $5 ; \mathrm{CREBBP}=\mathrm{CREB}$ binding protein $\mathrm{CRLF} 2=$ cytokine receptor like factor $2 ; \mathrm{EBF} 1=$ early $\mathrm{B}$-cell factor $\mathrm{l}$; ETV6 $=$ ets variant gene 6 (TEL oncogene); HSC = haemopoeticus őssejt; IKZFl = IKAROS family zinc finger l; JAKl / 2 = Janus-kináz l/2; KRAS = Kirsten rat sarcoma viral oncogene homolog; MLL = mixed-lineage leukemia; NFl = neurofibromin- 1 ; NRAS = neuroblastoma RAS viral (v-ras) oncogene homolog; PDG$\mathrm{FRB}=$ platelet derived growth factor receptor beta; $\psi \mathrm{LC}=$ pseudo-light chain complex; PTPNI 1 = protein tyrosine phosphatase, non-receptor type 11; RAG = recombination-activating gene; $\mathrm{RBl}=$ retinoblastoma- $1 ; \mathrm{RUNX1}=$ Runt-related transcription factor $1 ; \mathrm{TdT}=$ terminális dezoxinukleotidtranszferáz; TOX $=$ thymocyte selection associated high mobility group box; TP53 = tumor protein p53
\end{abstract}


gyakori, de előfordul a Philadelphia $(\mathrm{Ph})$-transzlokáció a $B C R$ és az $A B L I$ között.

2. Diszregulált expresszióhoz vezet egy onkogén intakt kódoló szekvenciájának transzlokációja aktívan átíródó gének enhancere mögé. Erre példa a CRLF2-vagy az EPOR-gén átrendeződése az immunglobulinok génszakaszába (IGH, IGK) B-sejtes ALL-ben [33].

3. Egyes esetekben a leukaemiás sejtek citogenetikailag normálisnak tünnek, de valójában pontmutációk vagy kisebb deletiók mutathatók ki alkalmas módszerekkel a kulcsfontosságú szabályozóproteinekben. Az ALLes gyermekek genomja a diagnóziskor átlagosan 10 20 nem csendes, a betegség szempontjából releváns kódoló szekvenciát érintő mutációt tartalmaz. Ennek körülbelül a kétszerese mutatható ki az esetenként relapsushoz vezető, általában más genetikai jegyeket is mutató minor szubklónokból [37, 40].

Ma már tudjuk azt is, hogy a genetikai változások nem véletlenszerü időben és differenciáltsági állapotban érik a lymphoblastokat, hanem jellemző patogenetikai sorrendben $[4,33]$. A haemopoeticus őssejteket (HSC) éró prediszponáló mutációkkal praeleukaemiás klónok alakulnak ki, és a belőlük származó lymphoid progenitorokban további betegséget iniciáló laesiók (fóként transzlokációk és génátrendeződések) társulnak. Általában szekunder mutációk változtatják meg a funkcióját a soron következő pre- és prosejtalakok fejlődési és differenciálódási faktorainak (növekedési faktorok receptorai, sejtciklust irányító proteinek). Ezt a folyamatsort jeleníti meg az 1. ábra.

A fejlett microarray-technikák igen közel hozták a leírt géneltérések rutinszerû vizsgálatát, melyeknek klinikai jelentôségük van a prognózis és a terápiaválasztás szempontjából [41]. Egyre több molekuláris target gyógyszeres gátlása biztosíthat jó klinikai kilátásokat a kemoterápiánál kedvezőbb mellékhatásokkal gyermekkori ALL-ben (3. táblázat). Talán a legismertebb közülük az imatinib, az ABL, KIT és PDGFR kinázok specifikus gátlószere, amelyet a korábban még csontvelő-transzplantáció mellett is a legrosszabb prognózisúnak tartott Philadelphia-pozitív $\left(\mathrm{Ph}^{+}\right)$ALL-ben is alkalmaznak [42]. Kemoterápiával kombinálva az ilyen esetek 85-95\%-ában tartós remisszió érhető el [43]. Használatának gátat szab a gyógyszerrel szembeni rezisztencia kialakulása (pontmutáció történik az ABL kinázdoménjében, az imatinib kötőhelyén), ezekben az esetekben hatékony második generációs tirozin-kináz-inhibitorok (TKI) állnak rendelkezésre (dazatinib, nilotinib és ponatinib; közülük ALL-ben jelenleg a nilotinib nem javallt). Az említett négy szer alkalmas még a NUP214-ABL1 fúzióval rendelkező T-sejtes és egyes úgynevezett $B C R-A B L 1$-szerú (Ph-like) B-sejtes ALL-esek kezelésére [22, 38].

A Ph-like genetikai alcsoportba tartozó betegeknél hiányzik ugyan a $B C R-A B L 1$-transzlokáció, ám a $\mathrm{Ph}^{+}$ ALL-esekhez igen hasonló mikro-RNS-expressziós profillal rendelkeznek. Nagy hányadukban mutált az IKZFl-gén $[40,44]$. A gyermekkori B-sejtes ALL-esek 15\%-át teszik ki, jellemzően magas a diagnóziskori fehérvérsejtszámuk, rosszul reagálnak a kemoterápiára, és rossz a túlélésük [45]. Jellemző genetikai rendellenességeik szerint a Ph-like betegek további kategóriákba oszthatók, azok szerint pedig molekuláris inhibitorokkal kezelhetők [42]. Az ABL-osztályba (ABL1, ABL2, PDGFRB, CSF1R) tartozó génátrendeződéssel rendelkező kemoterápiarefrakter betegek TKI-kezelése (dazatinib) kiváló eredményeket hozott [46]. A JAK2/EPOR átrendeződések és a Ph-like ALL-esek körülbelül felében meglévő $C R L F 2$-eltérések a $J A K 2$ aktiváló mutációjával asszociáltak, így ezekben az esetekben a JAK2-inhibitor ruxolitinib hatékonynak bizonyul [47].

Az ETV6-RUNX1 génfúzió hatására a haemopoeticus progenitorok homingját szabályozó gének hiszton-deacetilázok (HDAC) okozta csendesítése történik, azaz a sejtek elvesztik differenciációs képességüket. Ennek révén felmerült a tumorsejtekben apoptózist, illetve kiérést indukáló HDAC-inhibitor vorinosztát terápiás alkalmazása akut leukaemiákban [48]. A DNS-metiltranszferázinhibitor decitabinnal való kombinációja hatékony lehet relabált betegeknél is a malignus klón kemoszenzitivitásának helyreállításában és a korábbi DNS-metilációs mintázat újjáépítésében [49]. Szintén relapsusban értek el jó válaszkészséget a túlélési jelátvitelt célzó mTORinhibitorokkal (everolimusz, temszirolimusz) [50].

\section{Immunológiai alcsoportok és immunterápiás lehetőségek}

$\mathrm{Az}$ áramlási citometriai értékelést megkönnyítő, rutinszerü immunfenotipizálásra alkalmas leukaemiaspecifikus antigén nem ismert. A leukaemiás lymphoblastok antigénexpressziós profilja részben hasonló a normális B- és T-sejt-vonaléhoz [26]. Ez nem jelent teljes fenotípusos egyezést az egészséges sejtalakokkal, hiszen az aberráns, leukaemiaasszociált mintázat többféle módon létrejöhet, és sejtvonalbeli átfedéseket is mutathat (úgynevezett aszinkrón vagy cross-lineage antigénexpreszszió). Ehhez hasonlóan a T-ALL-es esetek 10-15\%-ában az immunglobulin-nehézlánc, míg B-ALL-ben gyakran a T-sejt-receptor (TCR) génátrendeződése figyelhető meg [3], amely rendellenességek szintén a sejtfelszíni receptor-összetételben hagynak nyomot.

A csontvelői és perifériás vérminták FC-s mérése során a blastpopulációk CD45-expresszió és oldalszórás szerinti kapuzással hagyományosan jól elkülöníthetők. Az ezt követő immunológiai osztályozást a lymphoid sejtalakok normális érési markerei segítik, az MRD követését pedig éppen a leukaemiás blastokat elkülönítő aberránsan kifejezett epitópok. Az ALL B-sejtes differenciációjának igazolására hasznos antigénnek bizonyult a CD19, a CD10 (CALLA), a CD79a, a HLA-DR, a citoplazmatikus CD22 és a nukleáris terminális dezoxinukleotid-transzferáz (TdT), de esetenként eredményre vezet a CD20, valamint a citoplazmatikus és sejtfelszíni immunglobulinstruktúrák (cIg és sIg) vizsgálata [19]. 
3. táblázat | Új terápiás célpontok és készítmények gyermekkori ALL-ben

\begin{tabular}{|c|c|c|}
\hline Hatóanyag & Target & Indikáció (megjegyzések) \\
\hline \multicolumn{3}{|c|}{ Célzott molekuláris inhibitorok } \\
\hline Imatinib & ABL, KIT, PDGFR & $\begin{array}{l}\mathrm{Ph}^{+} \mathrm{ALL} ; \text { NUP214 } A B L 1^{+} \text {T-sejtes ALL; ABL-osztályú Ph-like ALL (általában kombinálva } \\
\text { HSCT-vel) }\end{array}$ \\
\hline Dazatinib & $\begin{array}{l}\text { SRC-család, ABL, KIT, } \\
\text { PDGFR }\end{array}$ & Imatinib- és nilotinibrezisztens Ph+ ALL (kivéve a T315I, F317L és V299L mutánsokat) \\
\hline Nilotinib & ABL, KIT, PDGFR & Imatinibrezisztens $\mathrm{Ph}^{+}$ALL (kivéve a T315I, Y253H/F, E255V/K és F359 mutánsokat) \\
\hline $\begin{array}{l}\text { Aliszertib } \\
\text { AT9283 }\end{array}$ & Aurora-kinázok & Relabált, refrakter Ph+ ALL (hat a T315I és E255K mutánsokra?) \\
\hline $\begin{array}{l}\text { Lesztaurtinib } \\
\text { midosztaurin }\end{array}$ & FLT3 & $\begin{array}{l}M L L^{+} \mathrm{ALL} ; C D 117 / K I T^{+} \mathrm{T} \text {-sejtes ALL; hiperdiploid ALL; FLT3+ ALL } \\
\text { (a FLT3-overexpresszió gyakran társul az } M L L \text { és a KIT géneltéréseihez, illetve hiperdiploi- } \\
\text { ditáshoz) }\end{array}$ \\
\hline $\begin{array}{l}\text { Tipifarnib } \\
\text { Lonafarnib }\end{array}$ & Farnezil-transzferáz & $\begin{array}{l}\mathrm{Ph}^{+} \text {ALL (farnezil-transzferáz-inhibitorok hatására a Ras-fehérje funkcióját veszti; imatinib- } \\
\text { koterápia javasolt) }\end{array}$ \\
\hline Ruxolitinib & JAK2 & $J A K 2 / E P O R$ átrendeződés; Ph-like ALL-ben gyakori CRLF2-eltérések \\
\hline $\begin{array}{l}\text { Decitabin } \\
\text { Temozolomid }\end{array}$ & DNMT & $M L L^{+}$ALL (javasolt kombinálható szerek: vorinosztát, depszipeptid, valproát) \\
\hline $\begin{array}{l}\text { Vorinosztát } \\
\text { Panobinosztát } \\
\text { Romidepszin }\end{array}$ & HDAC & $\begin{array}{l}M L L^{+} \mathrm{ALL} ; \mathrm{Ph}^{+} \mathrm{ALL} \text { (javasolt kombinálható szerek: imatinib, rhTRAIL, agonista hatású } \\
\text { anti-TRAIL-receptor-antitestek, antraciklinek, flavopiridol) }\end{array}$ \\
\hline $\begin{array}{l}\text { Szirolimusz } \\
\text { Everolimusz }\end{array}$ & mTOR & Refrakter ALL \\
\hline MK-0752 & $\gamma$-Szekretáz & $\mathrm{NOTCHI}^{+} \mathrm{T}$-sejtes ALL \\
\hline $\begin{array}{l}\text { Bortezomib } \\
\text { Karfilzomib }\end{array}$ & $\mathrm{NF}-\kappa \mathrm{B}$ & Refrakter ALL; Ph+ ALL (a bortezomib volt az elsó proteaszómainhibitor) \\
\hline $\begin{array}{l}\text { Flavopiridol } \\
\text { Palbociklib }\end{array}$ & $\mathrm{CDK}$ & $\begin{array}{l}\text { Refrakter ALL; } \mathrm{Ph}^{+} \text {ALL (javasolt kombinálható szerek: rhTRAIL, citarabin, imatinib, } \\
\text { HDACi) }\end{array}$ \\
\hline $\begin{array}{l}\text { Oblimerzen } \\
\text { Venetoclax }\end{array}$ & BCL2 & Refrakter ALL (az oblimerzen egy antiszensz oligonukleotid) \\
\hline Taneszpimicin & HSP90 & $\mathrm{Ph}^{+} \mathrm{ALL} ; Z A P 70^{+} \mathrm{T}$-sejtes ALL (javasolt kombinálható szerek: HDACi) \\
\hline Trametinib & MEK & RAS-mutáns MLL+ ALL (serkenti a prednizolonszenzitivitást) \\
\hline \multicolumn{3}{|c|}{ Antitestalapú immunterápiás szerek } \\
\hline Rituximab & CD20 & CD20+ ALL (újabb anti-CD20 szerek: ofatumumab, obinutuzumab) \\
\hline Epratuzumab & CD22 & CD22+ ALL (rituximabbal kombinálva jobb eredmények, mint a két szernél külön-külön) \\
\hline Alemtuzumab & CD52 & CD52+ ALL (a legtöbb malignus T- és B-sejt expresszálja, de a CD34+ őssejtek nem) \\
\hline Blinatumomab & CD19 & $\mathrm{Ph}^{-}$refrakter/relabált CD19+ ALL \\
\hline $\begin{array}{l}\text { Denintuzumab- } \\
\text { mafodatin }\end{array}$ & CD19 & $\begin{array}{l}\text { Klinikai vizsgálat alatt (az antitesthez sejtciklust blokkoló anyag, monometil auristatin F } \\
\text { kapcsolódik, ami az internalizáció során a tumorsejtbe jut) }\end{array}$ \\
\hline DT2219 & CD19, CD22 & Klinikai vizsgálat alatt (rekombináns diftériatoxin-alapú immunotoxin) \\
\hline $\begin{array}{l}\text { Inotuzumab-ozoga- } \\
\text { micin }\end{array}$ & $\mathrm{CD} 22$ & $\begin{array}{l}\text { Klinikai vizsgálat alatt, jó eredményekkel (az antitesthez citotoxikus ágens, kalicheamicin } \\
\text { kapcsolódik, ami az internalizáció során a tumorsejtbe jut) }\end{array}$ \\
\hline Nivolumab & PDl & Relabált CD19+ ALL \\
\hline Ipilimumab & CTLA4 & Relabált CD19+ ALL \\
\hline
\end{tabular}

$\mathrm{ABL}=$ Abelson murine leukemia viral oncogene homolog; $\mathrm{ALL}=$ akut lymphoblastos leukaemia; BCL2 = B-cell CLL/lymphoma 2; CD = cluster of differentiation; CDK = cyclin dependent kinase; CRLF2 = cytokine receptor like factor 2; CTLA4 = cytotoxic T-lymphocyte-associated protein 4; DNMT = DNS-metiltranszferáz; DT2219 = bispecific ligand-directed toxin targeting CD22 and CD19; EPOR = erythropoietin receptor; FLT3 = fms related tyrosine kinase $3 ;$ HDAC = hiszton-deacetiláz; HDACi = hiszton-deacetiláz-inhibitor; HSCT = haemopoeticus őssejt-transzplantáció; HSP = heat shock protein; JAK2 = Janus-kináz-2; KIT = v-kit Hardy-Zuckerman 4 feline sarcoma viral oncogene homolog; MEK = mitogen-activated protein kinase kinase; $\mathrm{MLL}=$ mixed-lineage leukemia; $\mathrm{mTOR}=$ mechanistic target of rapamycin kinase; $\mathrm{NF}-\kappa \mathrm{B}=$ nuclear factor kappa-light-chain-enhancer of activated B cells; NOTCH = Notch (Drosophila)-homológ; NUP = nukleoporin; PDI = programozott sejthalál protein-1; PDGFR = platelet derived growth factor receptor; Ph = Philadelphia-kromoszóma; rhTRAIL = rekombináns humán tumornekrózisfaktorhoz hasonló apoptózist indukáló ligand; SRC = v-src avian sarcoma (Schmidt-Ruppin A-2) viral oncogene homolog; ZAP70 = zeta chain of T-cell receptor associated protein kinase 70 
A B-ALL-es esetek kétharmadát a korai pre-B-sejtes fenotípus teszi ki, a késői érési stádiumok (például CDl0negativitás) rosszabb prognózist jeleznek [3]. A T-ALL konszenzus markere a citoplazmatikus CD3-, a diagnózist segíti és a klón érési stádiumát pontosítja a CDl-, a CD2-, a CD5-, a CD7-, a TdT-, a citoplazmatikus, illetve sejtfelszíni CD4- és a CD8-antigén vizsgálata [19]. Meg kell említeni, hogy ALL-es sejteken 10-25\%-ban myeloid markerek is találhatók különösebb prognosztikai jelentőség nélkül. Valódi kevert fenotípusú akut leukaemiákban (MPAL) ezzel szemben a lymphoid és különösen a myeloid fenotipikus jegyek befolyásolják a kórjóslatot. Egyes ALL-es betegeknél a diagnóziskori immunfenotípus a relapsus idejére jelentősen módosul (úgynevezett lineage-shift jelenség) [3].

Az említett leukaemiaasszociált sejtfelszíni epitópok az alapjai az antitestalapú immunterápiának, ami a célzott molekuláris inhibitorokhoz hasonlóan a kemoterápiát kiegészítő, jóval kevesebb mellékhatással járó lehetőség az ALL gyógyításában (3. táblázat, 2. ábra). Klasszikus példa a rituximab elnevezésü kiméra anti-CD20 monoklonális antitest, amely a hatását apoptózisindukción, valamint antitestdependens sejtmediált, illetve komplementdependens citotoxicitáson (ADCC, illetve CDC) keresztül fejti ki. Továbbfejlesztett változata az erôsebb CDC-aktiváló ofatumumab és az obinutuzumab, az utóbbi a defukozilált kristályosítható fragmentuma $(\mathrm{Fc})$ révén az effektor immunsejt Fc $\gamma$ RIII-receptorához erōsebben kötődik [42]. Új vívmánynak számítanak a fehérjetervezéssel (protein engineering) fejlesztett bispecifikus T-sejt-kapcsolók (BiTE ${ }^{\circledR}$, bispecific T-cell engager), amelyek két úgynevezett egyláncú variábilis ellenanyag- fragmentumból (scFv, single-chain variable fragment; az immunglobulinok nehéz- és könnyúláncainak variábilis régióit fuzionáltatva) állnak össze. Idetartozik a blinatumomab, amelynek anti-CD19-karja a leukaemiás B-sejteket, anti-CD3-karja pedig a normális érett T-sejteket köti, kialakítva ezáltal egy szerkezetileg megfelelő immunológiai szinapszist a $\mathrm{CD} 19^{+}$targetsejtek apoptózisára, illetve lízisére $[42,51]$. A blinatumomab hatékonynak bizonyult Ph-negatív refrakter vagy relabált prekurzor B-ALL-es gyermekeknél [52]. Más fejlesztések során egyéb targetekhez kötődő immunglobulin-alegységekhez kémiailag kapcsoltak baktériumtoxint (DT2219; 2. ábra), citotoxikus ágenst (inotuzumab-ozogamicin) és radioizotópot $\left({ }^{90} \mathrm{Y}\right.$-ibritumomab-tiuxetán, ${ }^{131} \mathrm{I}$-tozitumomab) is. Ezek múködése a tumorsejt célepitópjához való kötés utáni gyors internalizáción alapszik [26, 42].

$\mathrm{Az}$ úgynevezett immunellenőrző pontokon az immunrendszer azon mechanizmusait értjük, amelyeknek feladata a szervezet saját antigénjeivel szembeni tolerancia fenntartása és a fiziológiás immunválasz modulálása [53]. A tumorsejtek immunfelügyelet alóli kikerülésének alapja ezen ellenőrző pontok inhibitoros fehérjéinek (CTLA4, citotoxikus T-lymphocyta antigén-4; PDl, programozott sejthalál protein-1) overexpressziója a tumoros mikrokörnyezet és az effektor T-sejtek közti immunológiai szinapszisban [51]. Ennek az immunrezisztenciamechanizmusnak a blokkolásán alapszik az immunonkológiában népszerú immunellenőrzőpontgátlók (ICI, immune checkpoint inhibitor; 2. ábra bal felső része) használata, amelyek egyre nagyobb teret nyernek a lymphoid malignitásokban is. Jó eredményekról számoltak be az anti-PDl monoklonális antitest ni-

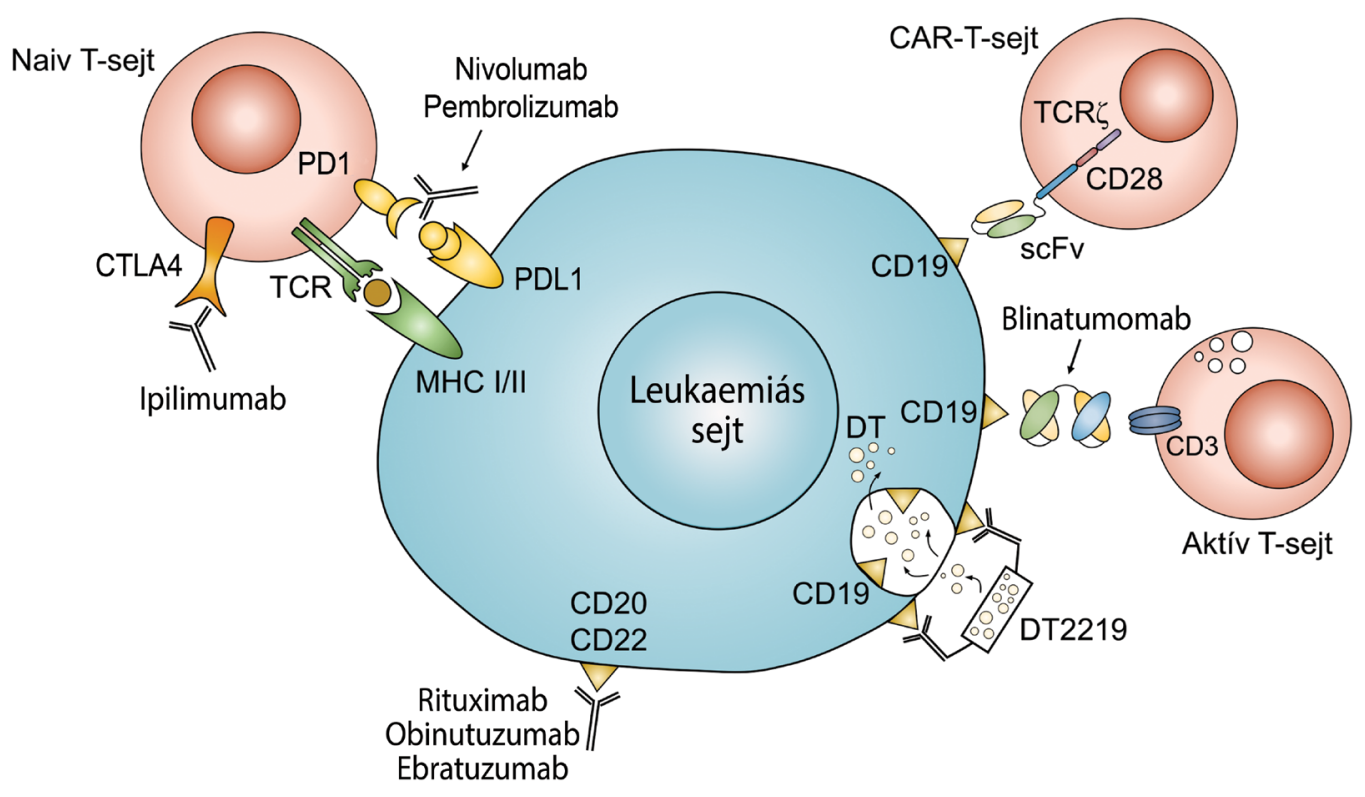

\begin{tabular}{l|l} 
2. ábra & $\begin{array}{l}\text { A leukaemiás sejt mint az immunterápia támadáspontja } \\
\text { CAR }=\text { kiméra antigénreceptor } ; \mathrm{CD}=\text { differenciációs klaszter; CTLA4 }=\text { citotoxikus T-lymphocyta antigén- } 4 ; \mathrm{DT}=\text { diftériatoxin; } \mathrm{MHC}=\mathrm{fő} \text { hiszto- } \\
\text { kompatibilitási komplex; } \mathrm{PDI} / \mathrm{PDLl}=\text { programozott sejthalál fehérje } / \text { ligand- } ; \text { scFv = egyláncú variábilis ellenanyag-fragmentum; TCR = T-sejt- } \\
\text { receptor }\end{array}$
\end{tabular} 
volumab használata kapcsán ALL-ben és lymphomákban [54]. A szintén anti-PDl hatású pembrolizumabbal és a CTLA4-inhibitor ipilimumabbal egyelőre klinikai vizsgálatok zajlanak, hematológiai vonatkozásban jobbára a kemoterápiára rosszul reagáló vagy relabáló lymphomákban [51].

A sejtes immunterápiák közül a kiméra antigénreceptorú (CAR) T-sejtek alkalmazása máig B-ALL-ben bizonyul a leghatékonyabbnak [51]. Lényege egy olyan genetikailag módosított autológ T-lymphocyta-populáció ex vivo létrehozása, amely specifikusan felismer bizonyos tumorasszociált antigéneket (TAA), következésképpen a leukaemiás B-lymphoblastokat célzottan képes pusztítani. Ehhez a felismeréshez szükséges a T-sejtek felszínén az úgynevezett CAR kifejeződése, amely tulajdonképpen fúziós fehérjéje egy specifikus TAA-kötő scFv-nek, a TCR egy aktiváló doménjének (tipikusan a ל̧-rész) és legalább egy kostimulációs molekulának (például CD28, 4-1BB). Ily módon a T-sejt-aktivációhoz elegendő csupán a targetantigén (általában CD19 vagy CD20 a malignus B-sejteken; 2. ábra) CAR általi felismerése, függetlenné téve a folyamatot a fó hisztokompatibilitási komplexektől (MHC). A CAR-T-sejtes terápia kivitelezése tipikus esetben három fó lépésből áll [51]:

1. Leukaferezis során a perifériás vér mononukleáris sejtjeinek (PBMC) gyújtése a betegtől, amelyekből a Tsejtek szeparálása általában anti-CD3 és anti-CD28 ellenanyaggal kapcsolt paramágneses mikrogyöngyökkel történik.

2. A CAR-t kódoló DNS-konstrukt transzdukciója (újabban az igen biztonságos "Sleeping Beauty" transzpozonrendszerrel, elektroporációt használva), majd a T-sejtek többhetes tenyésztése (CD3 és CD28 együttes stimulálásával) in vitro.

3. Prekondicionáló kemoterápiát követően az autológ CAR-T-sejtek infundálása a betegbe 1-2 napon át. A hatékony dózis testtömegkilogrammonként $1,5 \times 10^{6}$ $-3 \times 10^{7}$ sejt. Az in vivo CAR-T-sejt-expanzió körülbelül a 14. posztinfúziós napon éri el a csúcsát.

A CAR-T-sejtek terápiás alkalmazása több kilátástalan helyzetben levő (akár allogén haemopoeticus őssejttranszplantáció után) relabált ALL-es gyermeknél hozta közelebb a gyógyulást $[55,56]$. Biztatók az eredmények a CAR-T-sejtek in vivo perzisztenciáját elősegítő vakcináció, az allogén T-sejtek használata, a CD19-negatív relapsus megelőzése és a sejtterápia súlyos akut mellékhatásainak kezelése terén [42]. Az utóbbiak közül lényeges a technika egyik korlátját is jelentő úgynevezett citokinfelszabadulási szindróma, amely korszerü anticitokinterápiára (glükokortikoidok, etanercept, tocilizumab) több klinikai esetben jól reagált [55-58]. Megfontolandó továbbá az ICI-k együttes alkalmazása, amelynek révén a módosított T-sejtek által biztosított immunfelügyeletet a tumorsejtek kevésbé tudják elkerülni. Az USA Élelmiszer-biztonsági és Gyógyszerészeti Hivatala (FDA) 2017 augusztusában mint az első engedélyezett génterápiát hagyta jóvá a tiszagenlekleucelnek (Kym- riah $^{\mathrm{TM}}$, CTL019), egy autológ CAR-T-sejtes készítménynek a használatát gyermekkori relabáló és kezelésrefrakter B-ALL-ben.

\section{Következtetések és jövőbeli irányok}

Az elmúlt években komoly fejlődés történt az ALL patobiológiájának megértésében és a terápiarezisztens betegek hatékony, tumorbiológiai alapú, bizonyos mértékben már személyre szabott kezelésében. A következő években várhatóan befejeződik az ALL teljes genomikai feltérképezése. Ezzel kivilágosodnak a kezelési kudarcok biológiai okai, hiszen a kemorezisztencia mögött a legtöbbször speciális genetikai eltérések húzódnak meg. Szükséges lesz a magas relapsusrizikót már a diagnóziskor előre jelzô genetikai, immunológiai markerek identifikálása, hogy a célzott terápiás szerek alkalmazása idejében megkezdődhessen.

Az ABLl-gátló imatinib és dazatinib preklinikai vizsgálatok alapján nemcsak $\mathrm{Ph}^{+}$, hanem NUP214 $A B L 1$ átrendeződést mutató ALL-es sejtek ellen is hatékony. A jellemzően rövid túlélésú Ph-like ALL egyes betegeknél szintén $A B L$-eltérésekkel karakterizálható és TKI-ra jól reagál, míg mások a JAK2-EPOR átrendeződés és a CRLF2-eltérések révén a JAK2-gátló ruxolitinibbel kezelhetők. Az epigenetikai modifikáció (HDAC- vagy DNS-metiltranszferáz-inhibitor hatására) hatásos lehet a csendesített tumorszuppresszorok reaktiválásában $M L L$ átrendeződéssel rendelkező ALL-es csecsemőknél és CREBBP-mutációt hordozóknál. A leukaemiás lymphoblastok sejtfelszíni CD19-, CD20-, CD22-, CD52markerei konjugálatlan (például epratuzumab, rituximab) és immunotoxinnal vagy kemoterapeutikummal konjugált (például DT2219, inotuzumab-ozogamicin, moxetumomab-pazudotox) monoklonális antitestekkel is támadhatók. A bispecifikus blinatumomab antitest a leukaemiaellenes $\mathrm{CD}^{+}$effektor T-sejtek aktiválását végzi, de teret nyernek az ex vivo sejtterápiás módszerek is (CAR-T-sejtes immunterápia, dendritikussejt-alapú vakcina).

A Magyar Gyermekonkológiai Hálózat több központjában is alkalmazásra kerültek már innovatív gyógyszerek egyes, a hagyományos kezelésre nem reagáló és várhatóan rossz prognózisú ALL-es gyermekekben. Évek óta rutinszerü az imatinib és a dazatinib használata $\mathrm{Ph}^{+}$betegeknél, de újabban egyes Ph-like esetekben is adjuk. Néhány recidivált ALL-esnél biztató eredményekkel alkalmaztuk az inotuzumab-ozogamicint és a blinatumomabot. A Hálózat egységes törekvése a készítmények használatához elengedhetetlen molekuláris kritériumok (bizonyos CD-markerek, genetikai abnormitások jelenléte) vizsgálatának bóvítése a napi gyakorlatban a közeli jövőben.

A célzott molekuláris és immunterápiás eszköztár bővülése egybeesik az új patobiológiai faktorok azonosításával. Ismét helyet kap a hippokratészi gondolat: sokkal fontosabb azt tudni, milyen embert érint a betegség, 
mint azt, hogy milyen betegség érinti az embert. A fejlett molekuláris diagnosztika és a személyre szabott gyógyszerelés a gyermekkori ALL-t nemcsak közel teljesen gyógyítható betegséggé teheti, hanem elejét veszi a súlyos kezelésasszociált mellékhatásoknak is.

Anyagi támogatás: A közlemény megírása anyagi támogatásban nem részesült.

Szerzői munkamegosztás: E. B.: Részletesen tanulmányozta a szakirodalmat, megtervezte és megfogalmazta a kéziratot, megszerkesztette az ábrákat és a táblázatokat. K. G:. Kritikusan áttanulmányozta a közleményt, módosításokat javasolt, és pontosította a klinikai vonatkozásokat. E. D. J., M. J.: Áttekintette a szöveget, és hangsúlyozta a klinikailag fontos részeket. K. N., R. A., Cs. S. J., F. S. Á.: Követte és segítette a kézirat megírásának teljes folyamatát. A cikk végleges változatát valamennyi szerző elolvasta és jóváhagyta.

Érdekeltségek: A szerzőknek nincsenek érdekeltségeik.

\section{Irodalom}

[1] Arber DA, Orazi A, Hasserjian R, et al. The 2016 revision to the World Health Organization classification of myeloid neoplasms and acute leukemia. Blood 2016; 127: 2391-2405.

[2] Vardiman JW, Thiele J, Arber DA, et al. The 2008 revision of the World Health Organization (WHO) classification of myeloid neoplasms and acute leukemia: rationale and important changes. Blood 2009; 114: 937-951.

[3] Margolin JF, Rabin KR, Steuber CP, et al. Acute lymphoblastic leukemia. In: Pizzo P, Poplack D. (eds.) Principles and Practice of Pediatric Oncology. Lippincott Williams \& Wilkins, Philadelphia, PA, 2011; pp. 518-564.

[4] Inaba H, Greaves M, Mullighan CG. Acute lymphoblastic leukaemia. Lancet 2013; 381: 1943-1955.

[5] Pierro J, Hogan LE, Bhatla T, et al. New targeted therapies for relapsed pediatric acute lymphoblastic leukemia. Expert Rev Anticancer Ther. 2017; 17: 725-736.

[6] Asselin BL. Epidemiology of childhood and adolescent cancer In: Kliegman RM, Stanton BF, St Geme JW, et al. (eds.) Nelson Textbook of Pediatrics. Elsevier, Philadelphia, PA, 2016; pp. 2416-2418

[7] Garami M, Schuler D, Jakab Z. Importance of the National Childhood Cancer Registry in the field of paediatric oncology care. [Az Országos Gyermektumor Regiszter jelentősége a gyermekonkológiai ellátásban.] Orv Hetil. 2014; 155: 732-739. [Hungarian]

[8] Whitlock J, Gaynon P. Acute lymphoblastic leukemia in children. In: Greer J, Foerster J, Rodgers G, et al. (eds.) Wintrobe's Clinical Hematology. Lippincott Williams \& Wilkins, Philadelphia, PA, 2009; pp. 1889-1917.

[9] Greaves M. Infection, immune responses and the aetiology of childhood leukaemia. Nat Rev Cancer 2006; 6: 193-203.

[10] Pui CH, Robison LL, Look AT. Acute lymphoblastic leukaemia. Lancet 2008; 371: 1030-1043.

[11] Kinlen L. An examination, with a meta-analysis, of studies of childhood leukaemia in relation to population mixing. Br J Cancer 2012 ; 107: 1163-1168.

[12] Kinlen L. Infections and immune factors in cancer: the role of epidemiology. Oncogene 2004; 23: 6341-6348.
[13] Kroll ME, Draper GJ, Stiller CA, et al. Childhood leukemia incidence in Britain, 1974-2000: time trends and possible relation to influenza epidemics. J Natl Cancer Inst. 2006; 98: 417-420.

[14] Ottóffy G, Szigeti E, Bartyik K, et al. Investigating the relationship between mortality from respiratory diseases and childhood acute lymphoblastic leukaemia in Hungary. Pathol Oncol Res. $2015 ; 21: 53-57$.

[15] Swaminathan S, Müschen M. Infectious origins of childhood leukemia. Oncotarget 2015; 6: 16798-16799.

[16] Taylor G, Dearden S, Ravetto P, et al. Genetic susceptibility to childhood common acute lymphoblastic leukaemia is associated with polymorphic peptide-binding pocket profiles in $H L A$ $D P B 1^{*} 0201$. Hum Mol Genet. 2002; 11 : 1585-1597.

[17] Dorak MT, Lawson T, Machulla HK, et al. Unravelling an HLADR association in childhood acute lymphoblastic leukemia. Blood 1999; 94: 694-700.

[18] Amitay EL, Keinan-Boker L. Breastfeeding and childhood leukemia incidence: A meta-analysis and systematic review. JAMA Pediatr. 2015; 169: 9-11.

[19] Head D. Diagnosis and classification of the acute leukemias and myelodysplastic syndrome. In: Greer J, Foerster J, Rodgers G, et al. (eds.) Wintrobe's Clinical Hematology. Lippincott Williams \& Wilkins, Philadelphia, PA, 2009; pp. 1808-1819.

[20] Campana D, Pui C. Detection of minimal residual disease in acute leukemia: methodologic advances and clinical significance. Blood 1995; 85: 1416-1434.

[21] Gaipa G, Basso G, Biondi A, et al. Detection of minimal residual disease in pediatric acute lymphoblastic leukemia. Cytometry B 2013; 84B: 359-369.

[22] Eckert C, Hagedorn N, Sramkova L, et al. Monitoring minimal residual disease in children with high-risk relapses of acute lymphoblastic leukemia: prognostic relevance of early and late assessment. Leukemia 2015; 29: 1648-1655.

[23] Kotrova M, Trka J, Kneba M, et al. Is next-generation sequenc ing the way to go for residual disease monitoring in acute lymphoblastic leukemia? Mol Diagn Ther. 2017; 21: 481-492.

[24] Campbell M, Castillo L, Dibar E, et al. ALL IC-BFM 2009 protocol: a randomized trial of the I-BFM-SG for the management of childhood non-B acute lymphoblastic leukemia. ed. 2009.

[25] Kovács G. Acute lymphoblastic leukemia (ALL). In: Jeney A, Kralovánszky J. (eds.) Oncopharmacology. [Akut lymphoid leukaemia (ALL). In: Jeney A, Kralovánszky J. (szerk.) Onkofarmakológia.] Medicina Kiadó, Budapest, 2009; pp. 647-650. [Hungarian]

[26] Pui CH, Jeha S. New therapeutic strategies for the treatment of acute lymphoblastic leukaemia. Nat Rev Drug Discov. 2007; 6: 149-165.

[27] Pui CH, Evans WE. Treatment of acute lymphoblastic leukemia. N Engl J Med. 2006; 354: 166-178.

[28] Hjorth L, Haupt R, Skinner R, et al. Survivorship after childhood cancer: PanCare: a European Network to promote optimal long-term care. Eur J Cancer 2015; 51: 1203-1211.

[29] Wolthers BO, Frandsen TL, Baruchel A, et al. Asparaginase-associated pancreatitis in childhood acute lymphoblastic leukaemia: an observational Ponte di Legno Toxicity Working Group study. Lancet Oncol. 2017; 18: 1238-1248.

[30] Kutszegi N, Yang X, Gézsi A, et al. HLA-DRB1*07:01-HLA$D Q A 1 * 02: 01-H L A-D Q B 1 * 02: 02$ haplotype is associated with a high risk of asparaginase hypersensitivity in acute lymphoblastic leukemia. Haematologica 2017; 102: 1578-1586.

[31] Sági JC, Kutszegi N, Kelemen A, et al. Pharmacogenetics of anthracyclines. Pharmacogenomics 2016; 17: 1075-1087.

[32] Csordas K, Lautner-Csorba O, Semsei AF, et al. Associations of novel genetic variations in the folate-related and ARID5B genes with the pharmacokinetics and toxicity of high-dose methotrexate in paediatric acute lymphoblastic leukaemia. $\mathrm{Br} \mathrm{J}$ Haematol. 2014; 166: 410-420. 
[33] Hunger SP, Mullighan CG. Acute lymphoblastic leukemia in children. N Engl J Med. 2015; 373: 1541-1552.

[34] Müller J, Kovács G, Jakab Z, et al. Treatment results with ALLBFM-95 protocol in children with acute lymphoblastic leukemia in Hungary. [Az ALL-BFM-95 protokollal szerzett hazai eredmények akut lymphoblastos leukaemiás gyermekek kezelésében.] Orv Hetil. 2005; 146: 75-80. [Hungarian]

[35] Fulbright JM, Raman S, McClellan WS, et al. Late effects of childhood leukemia therapy. Curr Hematol Malig Rep. 2011; 6: 195-205.

[36] Diller L. Adult primary care after childhood acute lymphoblastic leukemia. N Engl J Med. 2011; 365: 1417-1424.

[37] Ma X, Edmonson M, Yergeau D, et al. Rise and fall of subclones from diagnosis to relapse in pediatric B-acute lymphoblastic leukaemia. Nat Commun. 2015; 6: 6604.

[38] Thompson MA. Molecular genetics of acute leukemia. In: Greer J, Foerster J, Rodgers G, et al. (eds.) Wintrobe's Clinical Hematology. Lippincott Williams \& Wilkins, Philadelphia, PA, 2009; pp. 1791-1807.

[39] Wiemels J, Cazzaniga G, Daniotti M, et al. Prenatal origin of acute lymphoblastic leukaemia in children. Lancet 1999; 354: 1499-1503.

[40] Mullighan CG. The molecular genetic makeup of acute lymphoblastic leukemia. Hematology Am Soc Hematol Educ Program 2012; 2012: 389-396.

[41] Yeoh EJ, Ross ME, Shurtleff SA, et al. Classification, subtype discovery, and prediction of outcome in pediatric acute lymphoblastic leukemia by gene expression profiling. Cancer Cell 2002; 1: 133-143.

[42] Santiago R, Vairy S, Sinnett D, et al. Novel therapy for childhood acute lymphoblastic leukemia. Expert Opin Pharmacother. 2017; 18: 1081-1099.

[43] Towatari M, Yanada M, Usui N, et al. Combination of intensive chemotherapy and imatinib can rapidly induce high-quality complete remission for a majority of patients with newly diagnosed $B C R-A B L$-positive acute lymphoblastic leukemia. Blood 2004; 104: 3507-3512.

[44] Mullighan CG, Miller CB, Radtke I, et al. $B C R-A B L 1$ lymphoblastic leukaemia is characterized by the deletion of Ikaros. Nature 2008; 453: 110-115.

[45] Roberts K, Li Y, Payne-Turner D, et al. Targetable kinase-activating lesions in Ph-like acute lymphoblastic leukemia. N Engl J Med. 2014; 371: 1005-1015.

[46] Kobayashi K, Miyagawa N, Mitsui K, et al. TKI dasatinib monotherapy for a patient with Ph-like ALL bearing ATF7IP/ PDGFR B translocation. Pediatr Blood Cancer 2015; 62: 1058 1060 .
[47] Mayfield J, Czuchlewski D, Gale J, et al. Integration of ruxolitinib into dose-intensified therapy targeted against a novel JAK2 F694L mutation in B-precursor acute lymphoblastic leukemia. Pediatr Blood Cancer 2017; 64: e26328.

[48] Johnstone RW, Licht JD. Histone deacetylase inhibitors in cancer therapy. Cancer Cell 2003; 4: 13-18.

[49] Burke M, Lamba J, Pounds S, et al. A therapeutic trial of decitabine and vorinostat in combination with chemotherapy for relapsed/refractory acute lymphoblastic leukemia. Am J Hematol. 2014; 89: 889-895.

[50] Daver N, Boumber Y, Kantarjian H, et al. A Phase I/II study of the mTOR inhibitor everolimus in combination with HyperCVAD chemotherapy in patients with relapsed/refractory acute lymphoblastic leukemia. Clin Cancer Res. 2015; 21: 27042714.

[51] Batlevi CL, Matsuki E, Brentjens RJ, et al. Novel immunotherapies in lymphoid malignancies. Nat Rev Clin Oncol. 2016; 13: $25-40$.

[52] von Stackelberg A, Locatelli F, Zugmaier G, et al. Phase I/Phase II study of blinatumomab in pediatric patients with relapsed/ refractory acute lymphoblastic leukemia. J Clin Oncol. 2016; 34 : $4381-4389$.

[53] Pardoll DM. The blockade of immune checkpoints in cancer immunotherapy. Nat Rev Cancer 2012; 12: 252-264.

[54] Chan TS, Sim JP, Kwong YL. Low-dose nivolumab-induced responses in acute lymphoblastic leukaemia relapse after allogeneic haematopoietic stem cell transplantation. Ann Hematol. 2017; 96: 1569-1572.

[55] Grupp SA, Kalos M, Barrett D, et al. Chimeric antigen receptor-modified $\mathrm{T}$ cells for acute lymphoid leukemia. N Engl J Med. 2013; 386: 1509-1518.

[56] Maude SL, Frey N, Shaw PA, et al. Chimeric antigen receptor T cells for sustained remissions in leukemia. N Engl J Med. 2014; 371: 1507-1517.

[57] Lee DW, Kochenderfer JN, Stetler-Stevenson M, et al. T cells expressing CD19 chimeric antigen receptors for acute lymphoblastic leukaemia in children and young adults: a phase 1 doseescalation trial. Lancet 2015; 385: 517-528.

[58] Maude SL, Laetsch TW, Buechner J, et al. Tisagenlecleucel in children and young adults with B-cell lymphoblastic leukemia. N Engl J Med. 2018; 378: 439-448.

(Kovács Gábor dr., Budapest, Tüzoltó utca 7-9., 1094 e-mail: kovacs.gaborl@med.semmelweis-univ.hu)

Az Orvosi Hetilap egyes számai megvásárolhatók a Mediprint Orvosi Könyvesboltban.

Cím: Budapest V., Múzeum krt. 17. - Telefon: 317-4948

A cikk a Creative Commons Attribution-NonCommercial 4.0 International License (https://creativecommons.org/licenses/by-nc/4.0) feltételei szerint publikált Open Access közlemény, melynek szellemében a cikk nem kereskedelmi célból bármilyen médiumban szabadon felhasználható, megosztható és újraközölhető, feltéve, hogy az eredeti szerző és a közlés helye, illetve a CC License linkje és az esetlegesen végrehajtott módosítások feltüntetésre kerülnek. 